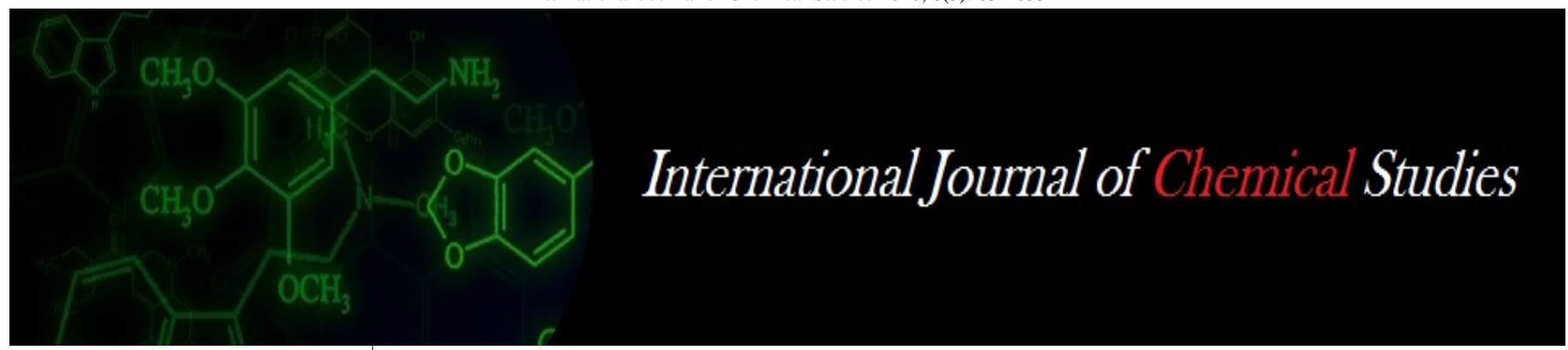

P-ISSN: 2349-8528

E-ISSN: 2321-4902

www.chemijournal.com

IJCS 2020; 8(3): 631-635

(C) 2020 IJCS

Received: 04-03-2020

Accepted: 06-04-2020

Md. Danish

College of Agricultural

Engineering, Dr. Rajendra

Prasad Central Agricultural

University, Pusa, Bihar, India.

Raushan Kumar

College of Agricultural

Engineering, Dr. Rajendra

Prasad Central Agricultural

University, Pusa, Bihar, India.

R.K. Sahu

Assistant Professor, College of Agricultural Engineering, Dr.

Rajendra Prasad Central

Agricultural University, Pusa,

Bihar, India.
Corresponding Author:

Md. Danish

College of Agricultural

Engineering, Dr. Rajendra

Prasad Central Agricultural

University, Pusa, Bihar, India.

\section{Effect of rate of organic mulch on soil moisture conservation}

\author{
Md. Danish, Raushan Kumar and R.K. Sahu
}

DOI: https://doi.org/10.22271/chemi.2020.v8.i3g.9277

Abstract

Proper utilization of water is essential particularly in arid and semi-arid areas. Mulching is an application of any plant residues or other materials for covering top soil surface for conserving soil moisture, reducing the runoff and thereby to control soil erosion, checking weed growth, improving soil temperature, modifying the micro environment of soil to meet the needs of seeds for their good germination and better growth of seedlings. This study was conducted in the field located in South Pangabri area near Rain-out shelter of Pusa Farm Samastipur, Bihar located in North Bihar, India. The RBD (Randomized Block Design) was considered for design of experiment. It investigated the effects of rate of organic mulches (Sugarcane leaf \& Paddy straw) on soil moisture conservation and on initial growth of Maize crop with different treatments $\mathrm{T}_{1}$ (No mulch), T2 (Paddy straw @ 3 t/ha), T3 (Paddy straw @6 t/ha), T4 (Paddy straw @9 t/ha), T5 (Sugarcane leaf @5 t/ha), T6 (Sugarcane leaf @10 t/ha), $\mathrm{T}_{7}$ (Sugarcane leaf @15 t/ha). The observations on soil moisture contents were taken from each treatment, replication-wise on alternate-day basis for four weeks period. The soil moisture content was determined by using oven drying method. Amongst different treatments, $\mathrm{T}_{6}$ is found most effective to conserve the highest level of moisture content in soil. The level of moisture conservation in this treatment ( $\mathrm{T}_{6}$ ) was found to the tune of about $20.17 \%$ (dry basis).

Keywords: Organic Mulch, Random Block Design, Moisture content, Treatments

\section{Introduction}

Mulch can be defined as any material on the soil surface through which continuous liquid water films from the soil are not present (Phillips, 1984) ${ }^{[7]}$. The traditional mulch consists of a well-aerated and therefore poorly conducting surface cover such as straw, leaf litter or gravel. Crop residues affect soil water content by having a direct effect on the evaporation from the soil surface and on the amount of water that infiltrates into the soil. Decreases in infiltration due to sealing of the pores caused by raindrop impact are reduced by residue cover. Crop residues significantly influence evaporation by affecting: 1) net radiation due to changes in surface albedo, 2) aerodynamic vapour conductance due to changes in wind speed, 3) resistance to vapour diffusion, which is dependent on mulch thickness, tortuosity and volumetric air fraction (Van Doren and Allmaras, 1978). Improving water efficiency is an ongoing goal in agricultural production, especially at the places where water resources are limited. One reason that there is a push to use less water in agriculture is because of increasing demand generated by the growing population. The water demands of urban populations are essentially fixed and growing, so water availability for agricultural producers is constantly reduced, and the associated costs rise. To address both of these issues, producers are searching for new ways to reduce their water demands. Mulching is one cultural practice which can be used to address this problem. Covering the ground with mulch saves water by preventing surface evaporation. The layer can also greatly reduce or eliminate weed propagation, which will also result in higher water use efficiency.

Using certain agricultural by-products as mulch is a sustainable practice which can reduce water use and provide other benefits as well. Wheat straw, grass clippings, sugarcane trass and leaf debris are fairly abundant by products. Many producers already generate these mulching materials, and currently spend resources to dispose of them. Mulching using this waste is a cost effective practice which would conserve water, moderate soil temperature, reduce waste, and improve the soil. (Pandey, 2016) ${ }^{[6]}$ Studied the effect of mulching on soil water 
conservation and soil temperature at Department of Soil \& Water Conservation Engineering at CAE, Pusa, Samastipur in year 2015. She used different types of mulches (Paddy straw, Rice husk, Sugarcane leaf, plastic sheet and saw dust) and found that plastic mulch conserved the moisture best followed by sugarcane leaf mulch. Hence, sugarcane leaf performed the best among the organic mulches used followed by paddy straw. Therefore, as a next step, the present study entitled "Effect of rate of organic mulch on soil moisture conservation" investigates the effects of rate of organic mulches (Sugarcane leaf \& Paddy straw) on soil moisture conservation and on initial growth of Maize crop with objectives assessing the effect of rate of organic mulch on soil moisture availability.

\section{Materials and Methods}

\section{Experimental Site and Climate}

The experimental work of this study was conducted in the field located in South Pangabri area near Rain-out shelter of Pusa Farm (Samastipur), Bihar. Samastipur district is located in North Bihar, on the southern and western bank of river Burhi Gandak at 2559' N latitude and 8548' E longitude. Altitude of the site is $52.92 \mathrm{~m}$ above of mean sea level.

Experimental site is under humid sub- tropical climate, greatly influenced by the south-west monsoon. The main characteristic of the climate is hot dry summer followed by cold winters. Average annual rainfall is $1270 \mathrm{~mm}$, out of which about $1026 \mathrm{~mm}$ is received during monsoon season from June to October. The period between the third week of December to first half of January, there are occasional winter showers. The hot weather commences from April and remains upto the middle of the June. The average maximum temperature during the hottest month from May to June varies from 37.5 to $40.6{ }^{\circ} \mathrm{C}$, and average minimum temperature for the same period is from 17.0 to $21.8{ }^{\circ} \mathrm{C}$, whereas monsoon average maximum temperature being about $33.9{ }^{\circ} \mathrm{C}$ and average minimum temperature is found in the tune of about $25.3^{\circ} \mathrm{C}$. January is the coldest month of the year with an average maximum temperature of $23.1{ }^{\circ} \mathrm{C}$ and minimum 7.7 ${ }^{\circ} \mathrm{C}$. Normally, the temperature starts decreasing from second fortnight of October and becomes minimum upto the end of December or early January. Again, it starts rising sharply from the end of February and maximum during May - June. The temperature rises to the highest degree during the month of May with $82 \%$ normal humidity at 7 A.M. The maximum humidity varies from 80 to $95 \%$ during the rainy months, while minimum 40 to $60 \%$ during the summer months. Highest solar radiation to the tune of 650 ly/day is received in the month of May, while lowest 380 ly/day during December.

\section{Experimental Design and Layout}

The RBD (Randomized Block Design) was considered for design of experiment. Experiment comprises total seven treatments and three replications. Table1 presents the details of experimental layout while Table 2 presents the details of treatments. Further distribution of different treatments along with respective replications is shown in figure 1.

Table 1: Details of the experimental layout

\begin{tabular}{|c|c|c|}
\hline Sl. No. & Particulars & Details \\
\hline 1. & Design & RBD (Randomised Block Design) \\
\hline 2. & Treatment & 7 \\
\hline 3. & Replications & 3 \\
\hline 4. & Total no. of plots & 21 \\
\hline 5. & Size of total plot area & $68 \mathrm{~m}^{2}$ \\
\hline
\end{tabular}

Table 2: Details of treatments followed in experimental design

\begin{tabular}{|c|c|}
\hline $\mathbf{T}_{1}$ & No mulch (control) \\
\hline T2 & Application of Paddy straw @ 3 t/ha \\
\hline T3 & Application of Paddy straw @ 6 t/ha \\
\hline T4 & Application of Paddy straw @ 9 t/ha \\
\hline T5 & Application of Sugarcane leaf @5 t/ha \\
\hline T6 & Application of Sugarcane leaf @10 t/ha \\
\hline T7 & Application of Sugarcane leaf @15 t/ha \\
\hline
\end{tabular}

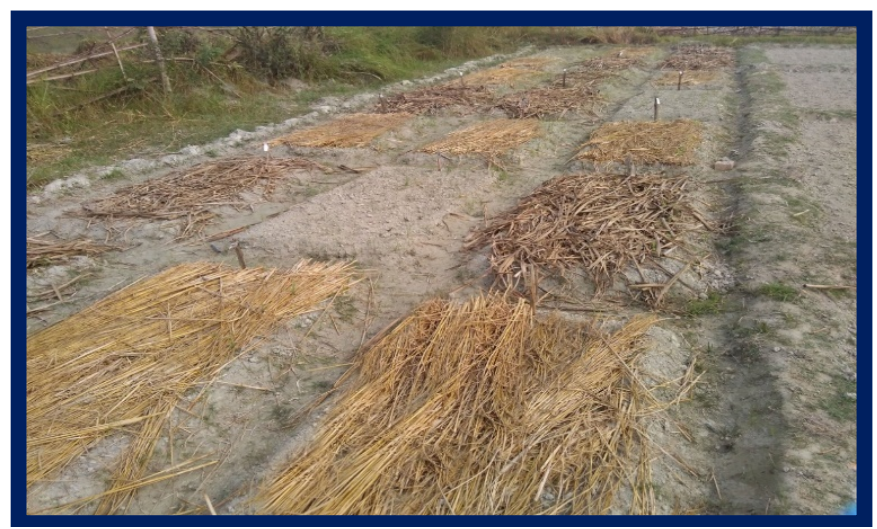

Fig 1: Photograph Showing the Details of Different Treatments

\section{Mulching \\ Mulch Materials}

In the research experiment, two types of organic mulch materials were used- paddy straw and sugarcane leaves. To make comparison of findings under different rates of mulches used with the natural condition, the un-mulched soil surface condition was also taken into account as control. The rate of application of mulch materials was decided as per reported values by different individuals (Rajput et al., $2014^{\text {[12]; Shah }}$ et al., $2014^{[10]}$ and Shaikh and Fouda, $2008^{[11]}$ ) along with the variations in the rates of the two mulches as presented in Figure 2.

\section{Mulching Procedure}

As per total number of treatments and replications to be followed, total 21 blocks of size $2 \mathrm{mx} 1 \mathrm{~m}$ were prepared separately on a field plot of 68 square metres $(17 \mathrm{mx} 4 \mathrm{~m})$ area. The soil of each block was thoroughly tilled and prepared into raised beds. Thereafter, mulching materials were laid as per the rate already presented in Table 2 in respective beds as per the experimental layout. The laying out of mulch materials was done in such a way that there should be formed a uniform layer of mulch on the soil surface; and also there is no exposure of soil surface for direct sun rays.

\section{Determination of Soil Moisture Content}

The observations on soil moisture contents were taken from each treatment, replication-wise on alternate-day basis for four weeks period, i.e. from $20^{\text {th }}$ November to $16^{\text {th }}$ December, 2016. The soil moisture content was determined by using oven drying method.

For determining soil moisture content, the soil sample from each plot was taken in moisture box of suitable size and known weight from each plot under all the treatments. The collected soil samples were kept in oven at $105^{\circ} \mathrm{C}$ for 24 -hour duration for completely drying or removal of moisture contents. However, prior to take soil samples in moisture box and placing them into oven for drying the following observations were taken:

1. Weight of moisture box; and

2. Weight of moisture box and soil sample. 
After keeping the moisture box along with soil sample in the oven for 24-hours duration, it is taken back and weighed properly. Finally, the moisture content (dry basis) of each soil sample was computed by using the following formula:

M. $C_{(\%)}=\frac{W_{w}-W_{d}}{W_{d}} x 100$

Where,

$W_{w}=W_{1}-W_{2}$

In which, $W_{1}$ is the weight of moisture box along with soil sample and $W_{2}$ is the weight of moisture box, and

$W_{d}=W_{3}-W_{2}$

In which, $W_{3}$ is the weight of oven dried soil sample along with moisture box.

\section{Analysis of Data}

For each treatment, the minimum, maximum and average value of moisture content was computed for the whole period i.e four weeks (20 Nov - 16 Dec).

\section{Results and Discussion}

This chapter deals the presentation of findings achieved and discussion on them under the project entitled "Effect of rate of organic mulch on soil moisture conservation" in comprehensive manner. In brief, the entire presentation has been bifurcated into three main heads for describing the derived results, as under:

\section{Effects of rate of Mulching Materials on Moisture Conservation}

In order to explore the effects of different rates of mulching materials i.e sugarcane leaves and paddy straw on moisture conservation, the observations on status of soil moisture content were taken for four weeks period (20/11/2016 to $16 / 12 / 16$ ) in the terms of soil sampling from each treatment and replications followed. The collected samples were further processed for determining the level of available moisture content. The determined moisture contents were analysed in line of percent variation in moisture conservation under different mulching materials as compared to the un-mulched (control) soil condition. The pertinent findings are presented in Figure- 3.

It is found that amongst different treatments of application of different rates of mulching materials, the treatment $\mathrm{T}_{6}$ (application of Sugarcane leaf @ $10 \mathrm{t} / \mathrm{ha}$ ) is found most effective amongst others to conserve the highest level of moisture content in soil. The level of moisture conservation in this treatment $\left(\mathrm{T}_{6}\right)$ was found to the tune of about $20.17 \%$ (dry basis). The average moisture content in treatment $\mathrm{T}_{7}$ is about $20.13 \%$ i.e., next to $\mathrm{T}_{6}$ for conserving the soil moisture followed by Paddy straw @ 9 t/ha $\left(\mathrm{T}_{4}\right)$, Sugarcane leaf @ 5 t/ha $\left(\mathrm{T}_{5}\right)$, Paddy straw@6 t/ha $\left(\mathrm{T}_{3}\right)$, Paddy straw @ 3 t/ha and control treatment (No mulch) condition with the level of moisture conservation to the tune of $19.90 \%, 19.67 \%$, $19.52 \%, 18.53 \%$ and $16.38 \%$, respectively.

Figure 2 also indicates that the Sugarcane leaf mulch @ 10 $\mathrm{t} / \mathrm{ha}\left(\mathrm{T}_{6}\right)$ was found to have highest increase $(23.13 \%)$ in moisture conservation followed by $\mathrm{T}_{7}$ (Sugarcane leaf mulch @ $15 \mathrm{t} / \mathrm{ha}$ ) (22.89\%) over control i.e no mulch condition. On the other hand, the lowest increase $(13.12 \%)$ was observed in case of $\left(\mathrm{T}_{2}\right)$ as compared to control treatment $\left(\mathrm{T}_{1}\right)$. In other rates of mulching materials such as Paddy straw@9t/ha ( $\left.\mathrm{T}_{4}\right)$, Sugarcane leaves mulch @ 5 t/ha $\left(\mathrm{T}_{5}\right)$, Paddy straw @6 $\mathrm{t} /$ ha $\left(\mathrm{T}_{3}\right)$, Paddy straw @ $3 \mathrm{t} / \mathrm{ha}$, the percent increase in moisture conservation was found $21.49 \%$, 20.05\%, 19.71\% and $13.00 \%$, respectively over control treatment.

Statistical analysis of moisture conservation data in respect of different rates of mulching materials, noticed the values of different statistical parameters such as SE (treatment mean), 0.291; CD (at 5\%), 0.906 (significant) and CV, 2.626, favours to significant effect of different treatments in line of moisture conservation.

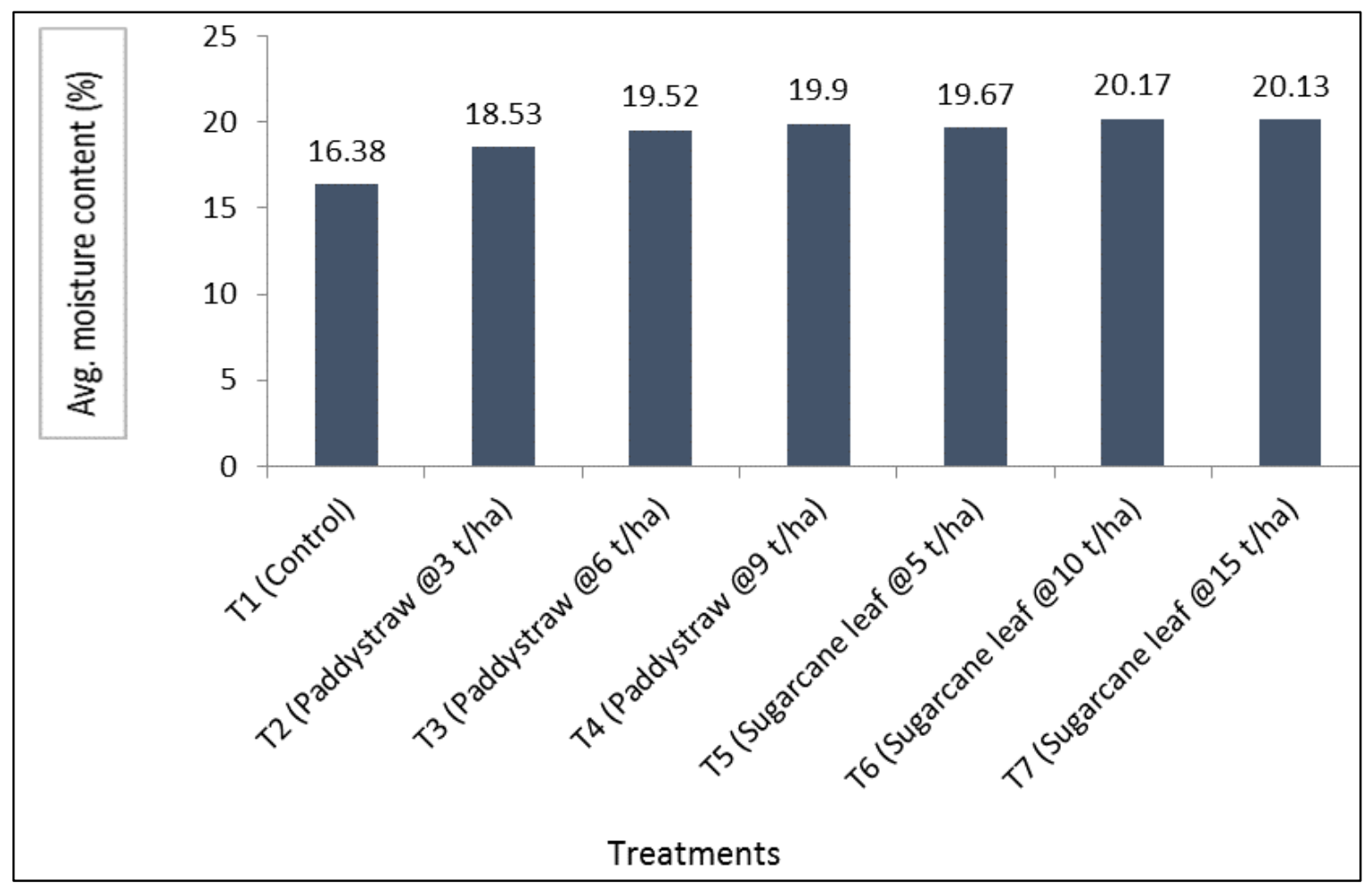

Fig 2: Extent of moisture conservation under different treatments 


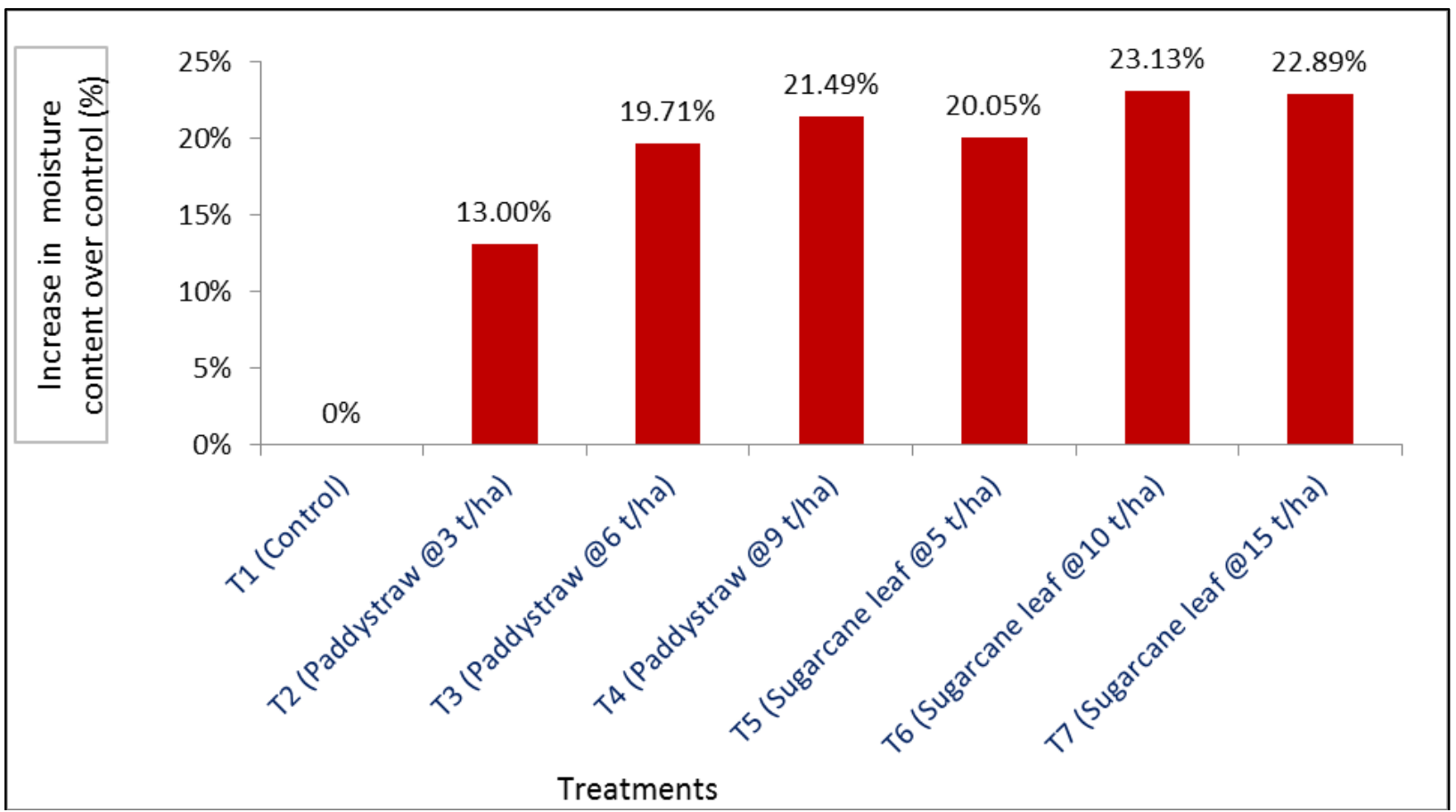

Fig 3: Percentage increase in extent of moisture conservation under different rate of mulching materials over un-mulched (control) condition

Extent of moisture conservation under different treatments is shown in figure1 while the percentage increase in moisture conservation under different rates of mulching materials over the control is shown in figure 3. It is obvious from these figures that the treatment $T_{6}$ is found to be best among all the treatments on the basis of moisture conservation.

The findings advocate that amongst different mulching materials with different rates, the Sugarcane leaf mulch @ 10 $\mathrm{t} / \mathrm{ha}$ is found to be the most suitable for moisture conservation in soil followed by Sugarcane leaf mulch @ 15 t/ha $\left(T_{7}\right)$, Paddy straw@9t/ha ( $\left.\mathrm{T}_{4}\right)$, Sugarcane leaves mulch@5 t/ha ( $\left.\mathrm{T}_{5}\right)$, Paddy straw@6 t/ha $\left(\mathrm{T}_{3}\right)$ and Paddy straw@ $3 \mathrm{t} / \mathrm{ha}$ in order. The highest level of moisture conservation in Sugarcane leaves mulch @ 10 t/ha might be because of appropriate quantity of mulch and type.

The Sugarcane leaves mulch @15 t/ha was found next to Sugarcane leaf mulch @10 t/ha for moisture conservation, it means that rate of mulch is not directly proportional to moisture content. Further, the other reasons may include the fact that due to excessive thickness of mulch, the moisture received through dense fog in the period of experiment (NovDec 2016) might not have reached to the soil. The variations in extent of moisture conservation in other mulching cases over un-matched condition is because of covering of soil surface; and there by the effect on moisture conservation and plant growth.

\section{Conclusions}

The observations on soil moisture contents were taken from each treatment, replication-wise on alternate-day basis for four weeks period, i.e. from $20^{\text {th }}$ November to $16^{\text {th }}$ December, 2016. The soil moisture content was determined by using oven drying method. Amongst different treatments, $\mathrm{T}_{6}$ is found most effective to conserve the highest level of moisture content in soil because of appropriate quantity of mulch and type. The level of moisture conservation in this treatment $\left(\mathrm{T}_{6}\right)$ was found to the tune of about $20.17 \%$ (dry basis). Further, the other reasons may include the fact that due to excessive thickness of mulch, the moisture received through dense fog in the period of experiment (Nov-Dec 2016) might not have reached to the soil. The variations in extent of moisture conservation in other mulching cases over un-matched condition is because of covering of soil surface.

\section{References}

1. Aniekwe N.L. Comparative effects of organic and plastic mulches on the environment, growth and yield of okra in a derived savanna zone of Nigeria, International Journal of Science and Research (online) ISSN 2319-7064. 2013.

2. Chaudhry M.R, Malik A.A, Sidhu M. Mulching Impact on Moisture Conservation - Soil Properties and Plant Growth, Pakistan Journal of Water Resources. 2004; 8:2.

3. Chavan M.L, Phad P.R, Khodke U.M, Jadhav S.B. Effect of organic mulches on soil moisture conservation and yield of rabi sorghum, International Journal of Agricultural Engineering. 2010; 35(1):322-328.

4. El-Shaikh A, Fouda T. Effect of different Mulching types on soil temperature and cucumber production under Libyan conditions, Journal of Agricultural Engineering. 2008; 25(1):160-175.

5. Mulumba L.N, Lal R. "Mulching effects on selected soil physical properties”. Soil and Tillage Research. 2008; 98:106-111.

6. Pandey S. "Effects of different mulching material on water conservation and soil temperature”, B.Tech (Agril. Eng) Project Report submitted to CAE, Pusa, Samastipur, 2016.

7. Phillips R.E. Effects of climate on performance of notillage, In No-tillage agriculture: Principles and practices. R.E. Phillips and S.H. Phillips (EDS.) Van Nostrand Reinhold, Inc, New York, 1984, 11-41.

8. Rajput B.S, Maurya S.K, Singh R.N, Sen A, Singh R.K. Effect of Different Types of Mulch on Maize under Guava (Psidium guajava) based Agri-Horti System. Department of Agronomy, BHU, Varanasi (UP), India, Online International Interdisciplinary Research Journal. 2014; 4:3.

9. Ramakrishna A, Tam H.M, Wani S.P, Long T.D. Effect of mulch on soil temperature, moisture, weed infestation 
and yield of groundnut in northern Vietnam Field Crops Research. 2006; 95(2-3):115-125.

10. Shah J.A, Memon M.Y, Depar N. Effect of Organic Mulching on Soil Moisture Conservation and Yield of Wheat, Pakistan Journal of Agricultural Engineering. 2014; 30(1):54-66.

11. Shaikh A, Fouda T. Effect of different mulching types on soil temperature and cucumber production under libyan conditions, Misr J Ag Eng. 2008; 25(1):160-175.

12. Singh R.K, Rajput S.B, Mauryaa S.K, Singhb R.N, Senb A. Effect of different types of mulch on maize under guava (Psidiumguajava) based Agri-Horti System. The International Journal of engineering and Science (IJES). 2014; 3(8):1805-2319.

13. Sinkeviciene A, Jodaugiene D, Pupaliene R, Urboniene $\mathrm{M}$. The Influence of organic mulches on soil properties and crop yield, Agronomy Research. 2009; 7(1):485-491. Source Type

14. Zribi W, Faciy J.M. Mulching effects on moisture, temperature, structure and salinity of agricultural soils. 2011; 107(2):148-162. 